\title{
Comparative Analysis on Essential Nutrient Compositions of 23 Wild Hazelnuts (Corylus heterophylla) Grown in Northeast China
}

\author{
Liying Fan $\mathbb{D}^{1},{ }^{1}$ Jun Ren, ${ }^{2}$ Yuting Yang, ${ }^{1}$ and Limin Zhang ${ }^{2}$ \\ ${ }^{1}$ Life Science and Technology Institute, Changchun University of Science and Technology, Weixing Road 7186, Changchun, China \\ ${ }^{2}$ Jilin Provincial Academy of Forest Sciences, Linhe Street 3528, Changchun, China \\ Correspondence should be addressed to Liying Fan; liyingfan5@126.com
}

Received 18 October 2019; Revised 31 January 2020; Accepted 25 February 2020; Published 31 March 2020

Academic Editor: Antoni Szumny

Copyright (c) 2020 Liying Fan et al. This is an open access article distributed under the Creative Commons Attribution License, which permits unrestricted use, distribution, and reproduction in any medium, provided the original work is properly cited.

The essential nutrients of 23 wild hazelnuts (Corylus heterophylla) grown in northeast China were analyzed in order to sieve good species and study the factors effected on nut quality. Hazelnut kernels contained $45.76-62.78 \%$ fat similar to Corylus avellana and main fatty acids were oleic acid (79.75\%), linoleic acid (15.42\%), palmitic acid (3.29\%), and polyunsaturated fatty acids ranged between $10.37 \%$ and $25.88 \%$. Average protein, soluble sugar, starch, and ash contents of hazelnut kernels were $25.12 \%$, $4.98 \%$, $2.03 \%$, and 3.04\%, respectively. The amount of amino acids, mostly as glutamic acid, arginine, and aspartic acid, was also determined by the hazelnut varieties. The abovementioned variation was explained by growing environmental differences. Among them, the 11th sample was highest in protein content (30.21\%) and 18th sample highest in fat content, while the 5th and 14th samples had relatively balanced nutrients. So, when planning to select new cultivars, we primarily considered different hazelnut qualities.

\section{Introduction}

There are about 20 species of Corylus around the world, widely distributed in temperate regions of Asia, Europe, and Americas. C. avellana is the most widely distributed variety in the world $[1,2]$ and is mainly grown in Turkey, Italy, Spain, and other countries for now, among which the Turkey's hazelnut production accounted for $70 \%$ of the world's total output $[3,4]$. Turkey' climate is hot and dry in summer and mild and rainy in winter, so C. avellana likes warm and humid climate, the place with plenty of light, and can adapt to a variety of soil. Also, China is the country of origin of Corylus, including C. heterophylla Fisch, C. mandshurica Maxim., C. kweichowensis $\mathrm{Hu}$, C. chinensis Franch, C. fargesii Schneid, C. yunnanensus A. Camus, C. ferox Wall, and C. wangii $\mathrm{Hu}$, distributed in over 20 provinces and autonomous regions [5]. The history of the use of wild hazelnut in China has been for 5000 6000 years [6], but systematic evaluation on chemical compositions of Chinese hazelnut has not been a more in-depth research.
Among China's origin, wild hazelnut, C. heterophylla, is the most economically valuable resource and is mainly distributed in Heilongjiang, Jilin, Liaoning, Neimongol, Hebei, and Shanxi provinces in China, but the resource of hazelnut is the largest and the quality is good in Northeast China [7]. In the region, the average precipitation and temperature are $460.8 \mathrm{~mm}$ and $7.7^{\circ} \mathrm{C}$, and the climate is cold and dry. So, this variety of hazelnut has good cold resistance, strong adaptability, and rich nutrition of kernel. China has obtained some progress in the utilization of wild C. heterophylla resources. It has been reported that there are some differences in nutritional quality compared with other hazelnut varieties $[5,8]$.

Hazelnut is a kind of favorite dried fruit which can be eaten raw and fried, not only delicious, but also has high calorific value $[9,10]$. In the food industry, hazelnut can be processed in cakes, confectionery, chocolates, and some senior nutrition such as ground hazelnut and hazelnut milk [11-13]. Hazelnut can be processed in oil. It is a kind of highquality edible oil rich in unsaturated fatty acid which has yellow color and flavor $[9,14-16]$. Besides the edible 
function, hazelnut oil can also be processed in soap, cosmetics, candles, etc [17]. According to the Chinese medicine book "Materia Medica for Dietotherapy," it is also a kind of medicine. Hazelnut has sweet taste, gentle effect, can strengthen the body, and benefit the stomach [6]. At present, the hazelnut processing industry in China is relatively single as mostly raw and fried food while the deep processing products are relatively few and mainly hazelnut oil, ground hazelnut, and hazelnut protein beverage [18]. The aim of this study is to compare the composition of different C. heterophylla growing in the Chinese northeast region and obtain wild $C$. heterophylla varieties with high nutrition. Furthermore environmental factors influencing the nutrient accumulation in hazelnut are also discussed. It can provide the selection of fine varieties for industry development of hazelnut and also offer basic information for intensive study of nutritional components of $C$. heterophylla.

\section{Materials and Methods}

2.1. Samples. Twenty-three samples of wild C. heterophylla were collected from the northeast region, including Jilin, Liaoning, Heilongjiang, and Neimongol Province of China (Figure 1, Table 1) by Jilin Provincial Academy of Forest Sciences in 2016 and used in this study. The hazelnut was naturally dried and the shell was broke to get the kernel samples after the harvest season. The hazelnut samples were polished and stored at $-18^{\circ} \mathrm{C}$ in the refrigerator.

2.2. Reagents. Twelve kinds of mixed standard fatty acid methyl esters (equal mass ratio), 20 kinds of amino acids, and D-(+)-glucose standard compounds were purchased from Sigma-Aldrich, Saint Louis, USA. Solvents for chromatography, namely hexane, acetone, methanol, hydrochloric acid, butanol, phosphate buffer solution and acetic acid were from Fisher Scientific, USA. Copper sulphate, sodium hydroxide, anthrone ethyl acetate, sulfuric acid, and boric acid were of analytical grade ( $>98 \%$; Merck, Darmstadt, Germany).

\subsection{Methods}

2.3.1. Water. The water content of samples was determined by drying at $103 \pm 2^{\circ} \mathrm{C}$ until they reached constant weight (AOAC, 925.40) [19].

2.3.2. Protein. Protein content was measured by the Kjeldahl method (Kjeltec 2300II, Foss, Sweden) [20]. Nitrogenous organic compounds in the samples were converted into ammonium sulphate, which further was reduced to molecular nitrogen. Protein content was calculated as total nitrogen by a conversion factor of 6.25 (AOAC 2001.11) [21].

2.3.3. Starch. In order to determine starch content, the acid hydrolysis method was used. $1 \mathrm{~g}$ dried residual extract removing soluble sugar and fat from each sample was homogenized with $30 \mathrm{ml}$ of $1 \mathrm{~mol} / \mathrm{L} \mathrm{HCl}$ in a water bath at $90^{\circ} \mathrm{C}$ for $2 \mathrm{~h}$ to hydrolyze the starch. The suspension was neutralized with $1 \mathrm{~mol} / \mathrm{L} \mathrm{NaOH}$, the sample was treated as previously described for soluble sugars according to GB 5009.9-2016 [22]. All analyses were conducted in triplicate for each variety.

2.3.4. Soluble Total Sugars. Quantitative determinations of soluble total sugars were carried out by the anthrone colorimetry method according to AOAC, 2000 [23]. $0.3 \mathrm{~g}$ hazelnut was extracted with $10 \mathrm{ml}$ water for $30 \mathrm{~min}$ in a boiling water bath. After filtration, $0.2 \mathrm{ml}$ filtrate and $1.8 \mathrm{ml}$ water were blended, then $0.5 \mathrm{ml}$ anthrone ethyl acetate reagent and $5 \mathrm{ml}$ sulfuric acid were added, fully oscillated, and then cooled down to room temperature, detected at $620 \mathrm{~nm}$ by using a UV-2550 spectrophotometer (Shimadzu Corporation, Kyoto, Japan).

2.3.5. Total Ash. Total ash was determined by using dried samples following the AOAC method 950.49 [24], and then the samples were weighed and the crucible was transferred to a muffle furnace. The temperature was preheated to $525^{\circ} \mathrm{C}$, and the samples were ashed for $4 \mathrm{~h}$ to a white powder. The crucibles were transferred into desiccators, cooled, and weighed.

2.3.6. Total Fat. Total fat was extracted with n-hexane $\left(60^{\circ} \mathrm{C}\right)$ for $8 \mathrm{~h}$ using a Soxhlet apparatus (AOAC method 948.22) [25]. Hexane was separated by evaporation at room temperature. The flasks were cooled and the crude fat was weighed.

2.3.7. Fatty Acid. Fatty acid composition was analyzed by gas chromatography (Thermo Trace 1300, USA) with a flame ionisation detector (FID). $\mathrm{N}_{2}$ was used as the carrier gas at a flow rate of $2 \mathrm{ml} / \mathrm{min}$. For separation of the fatty acids, a fused silica capillary column $(15.00 \mathrm{~m} \times 0.25 \mathrm{~mm} \times 25 \mu \mathrm{m}$ film thickness, provided by GE Company, New York, USA) was used and the temperature of the column and detector was set at $240^{\circ} \mathrm{C}$, and the injection temperature was $220^{\circ} \mathrm{C}$. Fatty acids were identified by comparison with retention times of external standards (AOCS, 1990) [26].

2.3.8. Free Amino Acids. Free amino acids were determined using a amino acid analyzer (S433D, Sykam, Germany). The amino acid analyzer was used with an Amino Sep Na + AA$911(250 \times 4.6 \mathrm{~mm})$ and ultraviolet-visible spectrometer (T6$1650 \mathrm{E}$, Persee, China) at $570 \mathrm{~nm}$.

2.4. Statistical Analysis. Statistical analysis of the data was performed using one-way ANOVA (SPSS Statistics 17.0, SPSS Inc. Chicago, USA). Differences were considered significant when $P<0.05$. All analyses were conducted in triplicate for each variety. 


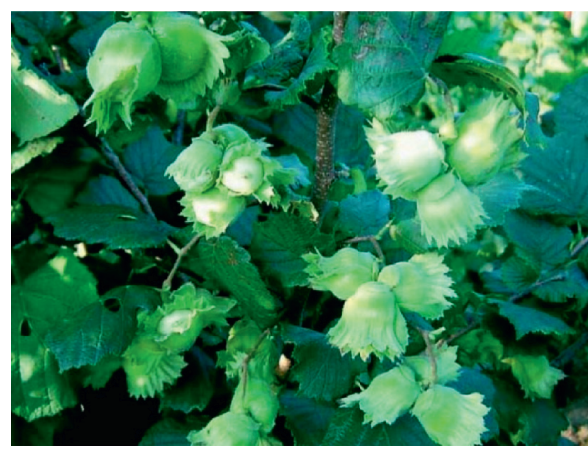

(a)

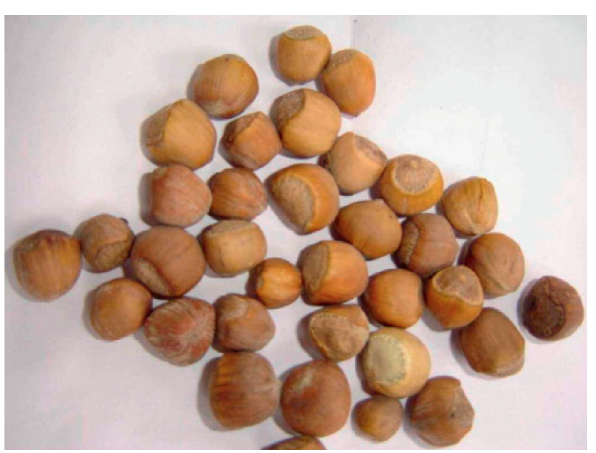

(b)

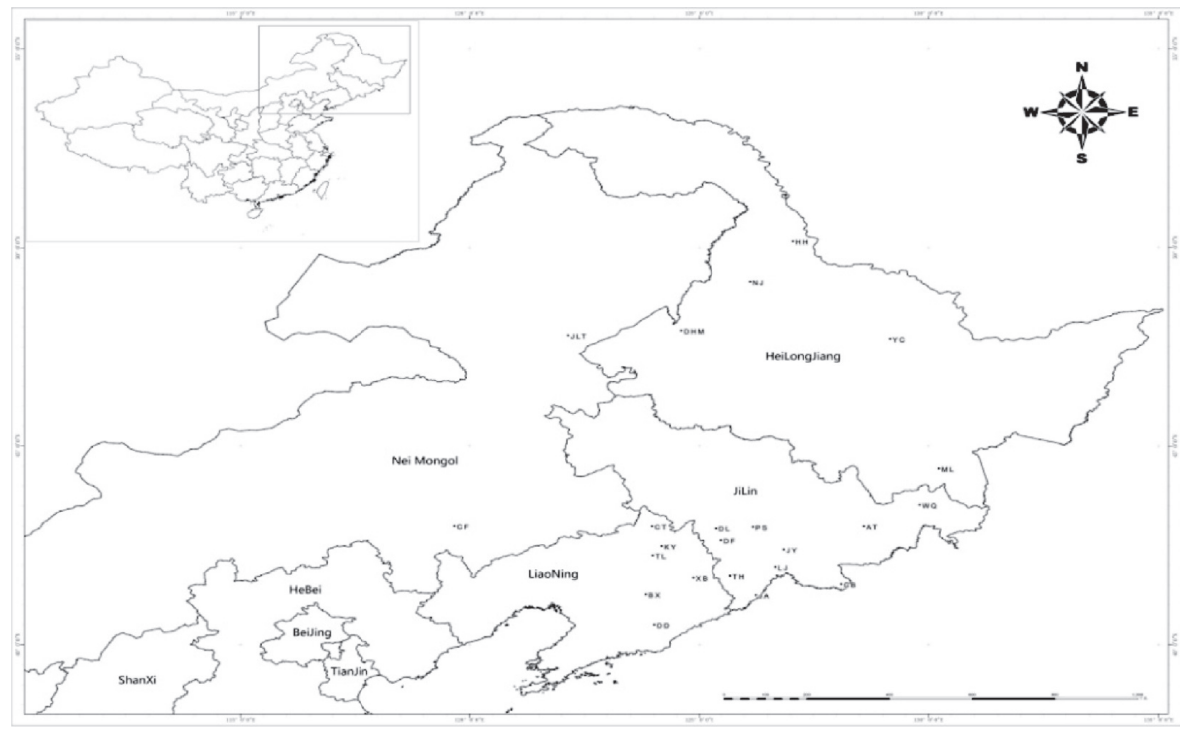

(c)

Figure 1: Wild hazelnut tree and fruits of C. heterophylla; distribution map of hazelnuts collected from the northeast region (Jilin, Liaoning, Heilongjiang, and Neimongol) of China.

TABLE 1: The collection location, abbreviation, and weight of 23 wild C. heterophylla samples tested in this study.

\begin{tabular}{|c|c|c|c|c|}
\hline Hazelnut variety & Location & Abbreviation & Weight (kg) & Longitude and latitude \\
\hline $\mathrm{P}-1$ & Da Hinggan Mountains of Heilongjiang & DHM & 6.000 & $124.1 \mathrm{e}, 50.42 \mathrm{n}$ \\
\hline $\mathrm{P}-2$ & Heihe of Heilongjiang & $\mathrm{HH}$ & 5.000 & 127.5 e, $50.25 \mathrm{n}$ \\
\hline $\mathrm{P}-3$ & Muleng of Heilongjiang & ML & 5.000 & 130.5 e, $44.92 \mathrm{n}$ \\
\hline $\mathrm{P}-4$ & Nengjiang of Heilongjiang & NJ & 5.000 & $125.2 \mathrm{e}, 49.17 \mathrm{n}$ \\
\hline P-5 & Yichun of Heilongjiang & YC & 5.000 & 128.9 e, $47.73 \mathrm{n}$ \\
\hline P-6 & Dongfeng County of Jilin & DF & 5.000 & $125.5 \mathrm{e}, 42.68 \mathrm{n}$ \\
\hline P-7 & Antu County of Jilin & AT & 7.000 & 128.3 e, $42.58 \mathrm{n}$ \\
\hline P-8 & Jian of Jilin & JA & 5.000 & 126.2 e, $41.15 \mathrm{n}$ \\
\hline P-9 & Jingyu County of Jilin & JY & 3.000 & $126.8 \mathrm{e}, 42.38 \mathrm{n}$ \\
\hline $\mathrm{P}-10$ & Linjiang of Jinlin & LJ & 3.000 & 126.9 e, $41.80 \mathrm{n}$ \\
\hline P-11 & Panshi of Jilin & PS & 5.000 & $126.0 \mathrm{e}, 42.93 \mathrm{n}$ \\
\hline $\mathrm{P}-12$ & Wangqing County of Jilin & WQ & 5.000 & 129.8 e, $43.32 \mathrm{n}$ \\
\hline P-13 & Tonghua County of Jilin & $\mathrm{TH}$ & 5.000 & 125.9 e, $41.49 \mathrm{n}$ \\
\hline P-14 & Benxi County of Liaoning & $\mathrm{BX}$ & 5.000 & $123.7 \mathrm{e}, 41.30 \mathrm{n}$ \\
\hline P-15 & Changtu County of Liaoning & $\mathrm{CT}$ & 5.000 & $124.1 \mathrm{e}, 42.80 \mathrm{n}$ \\
\hline P-16 & Dandong of Liaoning & DD & 5.000 & 124.4 e, $40.13 \mathrm{n}$ \\
\hline $\mathrm{P}-17$ & Kaiyuan of Liaoning & KY & 5.000 & 124.0 e, $42.53 \mathrm{n}$ \\
\hline P-18 & Tieling County of Liaoning & $\mathrm{TL}$ & 5.000 & $123.9 \mathrm{e}, 42.32 \mathrm{n}$ \\
\hline P-19 & Xinbing of Liaoning & $\mathrm{XB}$ & 5.000 & 125.0 e, $41.72 \mathrm{n}$ \\
\hline $\mathrm{P}-20$ & Cifeng of Neimongol & $\mathrm{CF}$ & 5.000 & 118.9 e, $42.28 \mathrm{n}$ \\
\hline $\mathrm{P}-21$ & Jalantun of Neimonggol & JLT & 5.000 & $122.7 \mathrm{e}, 48.00 \mathrm{n}$ \\
\hline $\mathrm{P}-22$ & Changbai County of Jilin & $\mathrm{CB}$ & 5.000 & $128.2 \mathrm{e}, 41.43 \mathrm{n}$ \\
\hline $\mathrm{P}-23$ & Dongliao County of Jilin & DL & 5.000 & 125.0 e, $42.92 \mathrm{n}$ \\
\hline
\end{tabular}




\section{Results and Discussion}

3.1. Nutrient Analysis. According to the measurement of nutritional composition, the content of water, starch, soluble total sugar, protein, total ash, and fat of 23 species of hazelnut kernels were presented in Figure 2: the water content changed between $3.45 \%(\mathrm{P}-5)$ and $5.00 \%(\mathrm{P}-4)$, the starch content ranged between $0.96 \%(\mathrm{P}-9)$ and $5.16 \%(\mathrm{P}-1)$, the soluble total sugar content changed between $2.95 \%(\mathrm{P}-5)$ and $9.20 \%(\mathrm{P}-2)$, the protein content changed between 21.38\% (P-18) and 30.21\% (P-11), the fat content changed between $45.76 \%(\mathrm{P}-11)$ and $62.78 \%(\mathrm{P}-18)$, and the total ash changed between $2.5 \%(\mathrm{P}-5)$ and $4.0 \%(\mathrm{P}-11)$. The fat was the predominate component in all hazelnut kernels, and protein was the second major component, followed by soluble total sugar, water, total ash, and the starch [27-29].

Varieties of the hazelnut nutrition exhibit a few difference, and some of them are significant $(P<0.05)$. The amount of variation was explained by environmental factors of all variables investigated, such as temperature, latitude, rain, sunshine time, and soil composition $[15,16]$. Larger temperature difference between day and night and high latitudes probably benefit sugar and starch accumulation, and high temperature and low latitudes (much rain and long sunshine time) are good for fat synthesis. Among all hazelnut kernels, $\mathrm{P}-11$ presented higher protein $(30.21 \%)$, soluble sugar $(8.02 \%)$, water $(4.94 \%)$ and ash $(4.00 \%)$, and lower total fat $(45.76 \%)$; P-18 presented highest total fat $(62.78 \%)$, and lower protein $(21.38 \%)$, soluble sugar $(3.82 \%)$, starch $(1.57 \%)$, and ash (2.60\%). Maybe it is because Panshi of Jilin is located at the foot of ChangBaishan Mountains and has a large temperature difference, while Tieling County of Liaoning is laid on the middle of Songliao Plain and the climate is warm and rainy. If compared with P-11 (high protein) and P-18 (high fat), it seemed that P-5 and P-14 had relatively balanced nutrients. Nutritional quality can be used as an important indicator in the selection and promotion of dominant varieties of hazelnut. In the production, it can be selected and produced according to different needs.

3.2. Water and Ash Content. There were differences in water content of different varieties, and the mean value was $4.18 \%$. The water content of P- 4 was higher than that of other species, while the degree of drying was consistent with the harvest time, storage conditions, and transportation ways of different varieties of hazelnut [30]. Low water content was benefit to prolong the storage time of hazelnut kernel. Ash mainly reflected the content of inorganic elements, for example, $\mathrm{Ca}$, $\mathrm{Mg}, \mathrm{K}, \mathrm{Na}, \mathrm{Si}, \mathrm{P}, \mathrm{S}, \mathrm{Fe}, \mathrm{Al}$, etc. The average ash content of the hazel varieties was found to be $3.04 \%$ and higher than $C$. avellana [27]. The minimum and maximum values were distinctions between compositions of the hazelnut varieties, based on mineral compositions of the soil in different regions. The soil in Northeast China is mainly black soil and chernozem, rich in humus, $\mathrm{Ca}, \mathrm{Mg}, \mathrm{Fe}, \mathrm{K}, \mathrm{Na}$, and so on [31].

3.3. Soluble Sugars and Starch Content. High levels of soluble sugars were also observed in $\mathrm{P}-1, \mathrm{P}-2, \mathrm{P}-4, \mathrm{P}-7, \mathrm{P}-11$, and

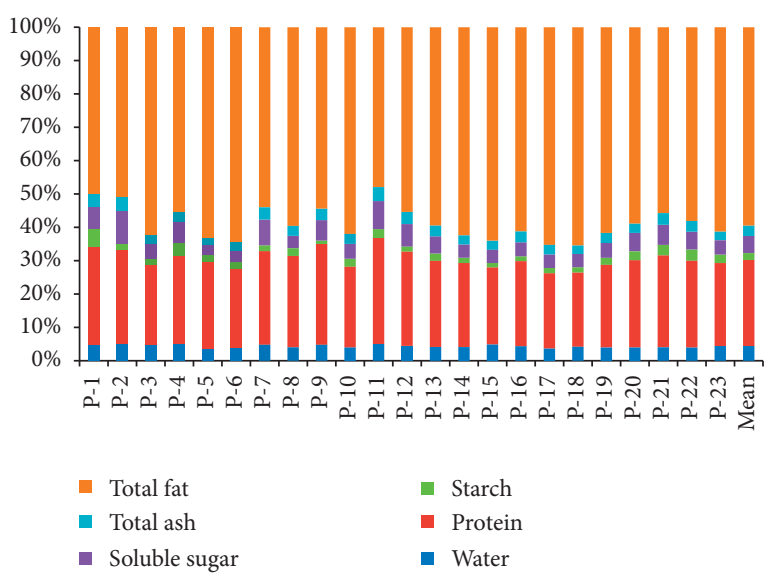

FIGURE 2: The content of water, protein, starch, soluble sugar, total ash, and total fat of hazelnut kernel from different areas (Northeast of China). Each value is a mean of three determinations.

P-12, whose values were above $6 \%$. Sugar content differed among areas; the average content of Heilongjiang' western and Jilin' eastern mountain area was $7.23 \%$, a value obviously higher than those in the other areas (P-14 23, 3.97\%). Due to the large temperature difference between day and night in mountain area, it is probably benefit for sugar accumulation [32]. These differences in sugar content confirmed previous results [27] and should help in cultivar characterization. Even if present at low concentrations, sugar should be involved in kernel taste and favor; thus it plays an important role in nut quality determination [33].

Starch content showed markedly differences among areas (Figure 2). The mean value of starch content was lower in samples collected in Liaoning' east regions than those collected in others, whereas soluble sugar levels were lower. This result is consistent with the capacity of high temperature to modify seed composition, where the proportion of soluble sugars to starch decreases with increasing temperature [34]. Eastern regions of Liaoning province were characterized by relatively low latitudes and high temperatures.

3.4. Total Fat and Fatty Acid. The total average fat content ranged between $45.76 \%$ in $\mathrm{P}-11$ and $62.78 \%$ in $\mathrm{P}-18$, with significant differences among samples (Figure 2). P-3, P-5, P-6, P-10, P-15, P-17, and P-18 contained more oil (61.00\%) than the other samples. Palmitic (C16:0), stearic (C18:0), oleic $(\mathrm{C} 18: 1)$, linoleic $(\mathrm{C} 18: 2)$, arachidic $(\mathrm{C} 20: 0)$, and linolenic (C18:3) acids were the main fatty acids to be identified. The analysis of variance indicated distinct differences in fatty acid composition among samples, as shown in Figure 3.

The main fatty acid was oleic acid (C18:1), ranging between $85.53 \%$ in P-5 and $69.80 \%$ in P-2, consistent with results reported [15]. Linoleic acid (C18:2) showed pronounced differences among samples, the lowest content being found in P-5 (10.24\%) and the highest in P-2 (25.65\%). A negative relationship between oleic and linoleic acids was observed (Figure 3(a)), as previously reported by Parcerisa 


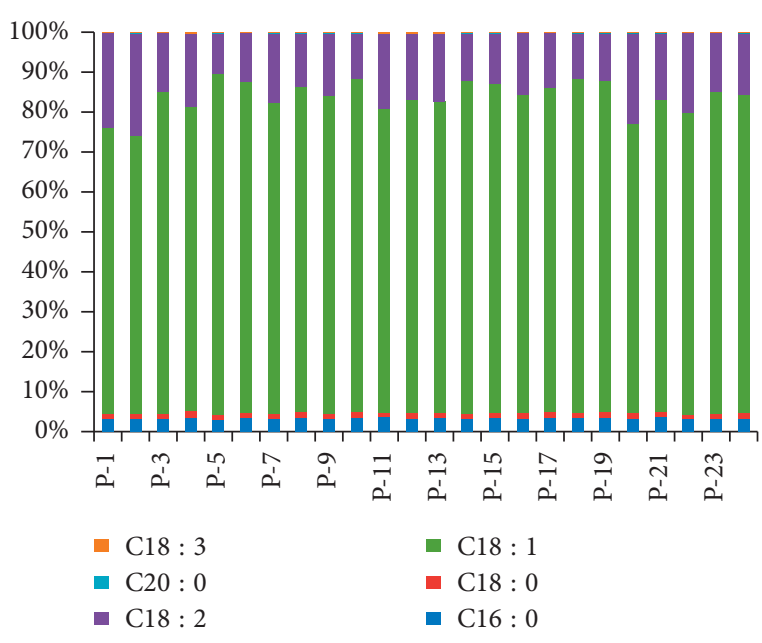

(a)

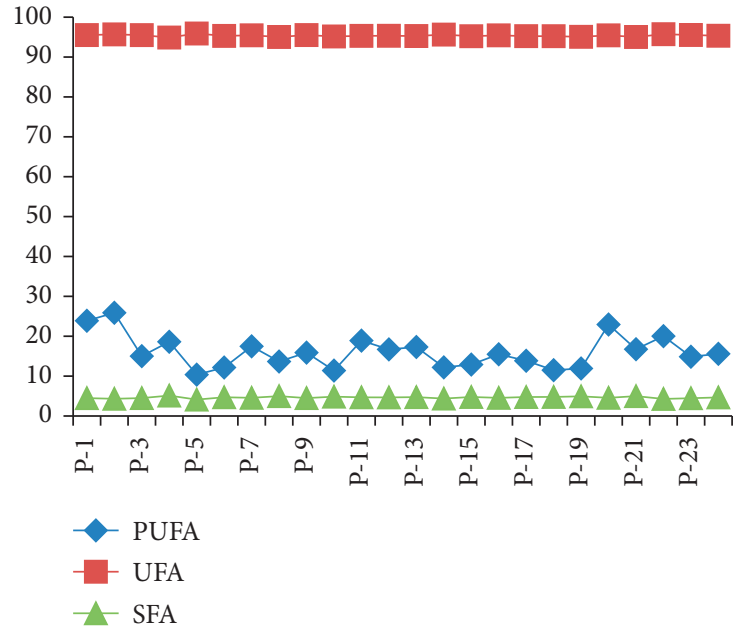

(b)

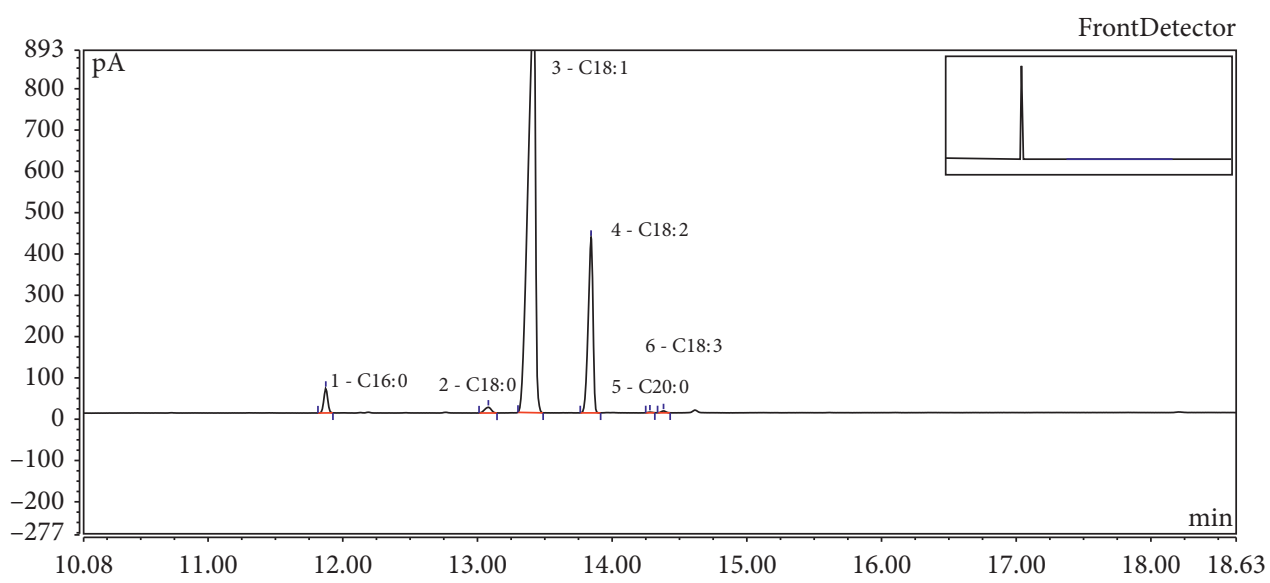

(c)

FIgUre 3: (a) Fatty acid composition (\%) of total fat. (b) Polyunsaturated fatty acids (PUFA), unsaturated fatty acids including polyunsaturated and monounsaturated (UFA), and saturated fatty acids (SFA) of hazelnut kernel from different areas (Northeast of China). (c) Fatty acid profile of the hazelnut by gas chromatography. Each value is a mean of three determinations.

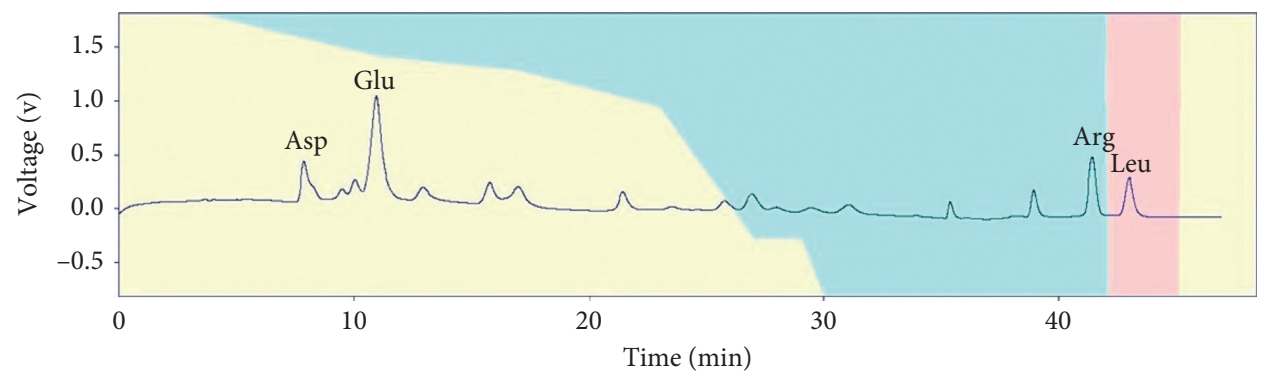

Figure 4: Amino acid profile of the hazelnut by using an amino acid analyzer.

et al. [16]. Moreover, P-1, P-2, P-20, and P-22 were characterized by the highest levels of linoleic acid and polyunsaturated fatty acids (PUFA), which was more than $20.00 \%$ [35]. Linolenic acid (C18:3) ranged between $0.10 \%$ in P-6 and $0.32 \%$ in $\mathrm{P}-11$. This fatty acid, even in traces, can negatively affect nut storability because of its low stability $[36,37]$, but was healthy for human physical well-being [38].
The saturated fatty acid (SFA) content was less than $6 \%$ of the total in all samples, ranging between $4.11 \%$ in P-5 and $5.12 \%$ in P-4 (Figure 3(b)). The predominant SFA was palmitic acid (C16:0) whose content ranged between $2.91 \%$ in P-5 and $3.75 \%$ in P-11. The mean levels of ostearic acid (C18:0) were quite variable, ranging from $0.81 \%$ in $\mathrm{P}-11$ to $1.63 \%$ in $\mathrm{P}-4$. The differences among samples could 


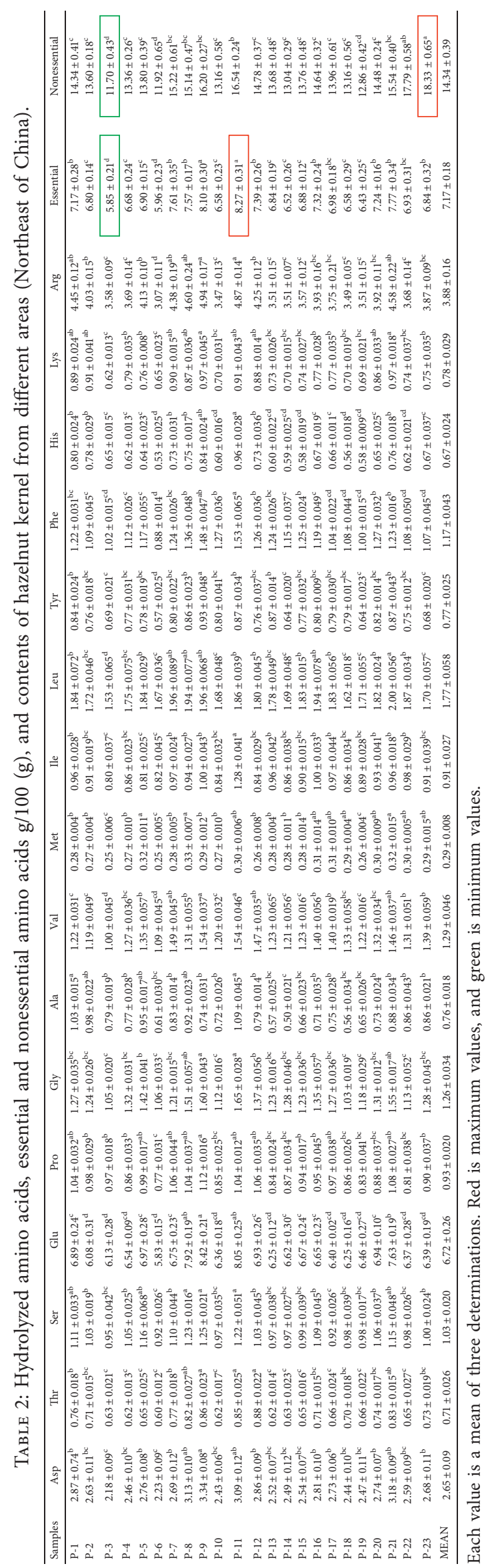


be relevant to the harvesting period, geographical location, and genetic mutation [37]. At the same time, these differences should be dependent on climatic conditions during the growing season, in particular, during the summer months.

In Liaoning province, the summer was relatively hot, with a mean maximum temperature in June, July, and August about $3^{\circ} \mathrm{C}$ higher and a mean minimum temperature $1.9^{\circ} \mathrm{C}$ higher than in 2016 . So, the PUFA content of C. heterophylla from Liaoning province was not beyond $20.00 \%$. Climate and latitude of cultivation are among the factors which can affect the unsaturated degree of fatty acid and the percentage of different fatty acids in C. avellana. [39]. It was the same as other oil seeds such as olive and walnut. Olive fruits from cool areas contain oil with more unsaturated fatty acids than fruits from dry and warm areas [40]. In walnut, models of the response of fatty acid composition to temperature have been proposed as a basis for oil quality prediction [41].

So, fat is the most important nutrients in C. heterophylla and it is in accordance with C. avellana. Unsaturated fatty acids with health properties, mainly oleic $(\mathrm{C} 18: 1)$ and linoleic (C18:2), are high levels. P-15, 17, 18 show relatively high fat content, but the weak point on nutrition is attenuated by low level of other compositions. There are differences between the flavor, of which may be related to the different compositions and contents of fatty acids in hazelnut oil.

3.5. Total Protein and Free Amino Acid. In this study, all of the hazelnuts had protein contents above $20.00 \%$, and the mean value was $25.13 \%$ (Figure 1) [42]. We find that protein was the second important nutrient composition in hazelnut kernels and are parallel results of Köksal et al. [27]. There are sixteen different kinds of amino acids including seven essential and nine nonessential amino acids (Figure 4, Table 2). The content of total essential and nonessential amino acids ranged from $5.85 \%(\mathrm{P}-3)$ to $8.27 \%(\mathrm{P}-11)$ and from $11.70 \%$ (P-3) to $18.33 \%$ (P-23), respectively.

It was mostly composed of nonessential amino acids such as glutamic acid, arginine, and aspartic acid. In the protein of all hazelnut varieties, glutamic acid was determined as the most predominant nonessential amino acid [43], with amounts between 5.83\% (P-6) and 8.42\% (P-9), and a mean value of $6.72 \%$ for the twenty-three different samples. The second major amino acid was the arginine in a range from $3.07 \%(\mathrm{P}-6)$ to $4.94 \%$ (P-9), with a mean value of $3.88 \%$, followed by aspartic acid ranging from $2.18 \%(\mathrm{P}-3)$ to $3.34 \%$ (P-9), the glycine ranging from $1.05 \%$ (P-3) to $1.65 \%$ $(\mathrm{P}-11)$, the proline ranging from $0.81 \%(\mathrm{P}-22)$ to $1.12 \%(\mathrm{P}-$ 9 ), etc. Based on the mean values of $0.29 \%$, methionine was found at the lowest level for all hazelnut varieties.

Except for nonessential amino acid, leucine, valine, lysine, phenylalanine, threonine, and iosleucine were determined as the essential amino acids. Leucine and valine were found as the most abundant (Table 2), which levels in the samples ranged between $1.53 \%(\mathrm{P}-3)$ and $2.00 \%(\mathrm{P}-21)$ and $1.00 \%(\mathrm{P}-3)$ and $1.54 \%(\mathrm{P}-9,11)$, respectively. But, based on the mean values of the samples, threonine $(0.60 \%-0.88 \%)$ was the most nonobvious amino acid. As a result of this research, hazelnut seems to be a good source of protein and also amino acids, but there are not enough further studies on hazelnut protein and amino acids [44].

The protein content in C. heterophylla is higher than that of C. avellana, and the amino acid profile showed that it is a good source of amino acids including sixteen kinds of amino acids with nutrition effects, such as glutamic acid, arginine, and aspartic acid. P-1, -9, and -11 appear at high concentrations in protein content and low concentrations in fat content. The information relating other components is useful for discriminating hazelnut, and we think P-5 and P-14 had relatively balanced nutrients.

\section{Conclusion}

Therefore, C. heterophylla is a valuable wild product, based on its beneficial nutrient composition, especially for human health. This study is helpful to screen different targets that put together targets of high level of nutritional components through comparison. However, certain growing conditions and genetic variations influencing the nutritional value of hazelnut varieties will be the subject of further research projects.

\section{Data Availability}

The nutrient data used to support the findings of this study are included within the article.

\section{Conflicts of Interest}

The authors declare no conflicts of interest.

\section{Acknowledgments}

The authors acknowledge the Forestry Department of Jilin Province (nO.2015-005) and Science and Technology Department of Jilin Province (nO.20180201007NY) for financial support to carry out the work. They also thank Jilin Academy of Agricultural Science for the facilities provided and technical support.

\section{References}

[1] M. Contini, S. Baccelloni, R. Massantini, and G. Anelli, "Extraction of natural antioxidants from hazelnut (Corylus avellana $L$.) shell and skin wastes by long maceration at room temperature," Food Chemistry, vol. 110, no. 3, pp. 659-669, 2008.

[2] V. Schmitzer, A. Slatnar, R. Veberic, F. Stampar, and A. Solar, "Roasting affects phenolic composition and antioxidative activity of hazelnuts (Corylus avellana L.)," Journal of Food Science, vol. 76, pp. 14-18, 2011.

[3] T. Demir and N. Beyhan, "Research on the selection of hazelnuts grown in Samsun," Turkish Journal of Agricultural and Forestry, vol. 24, pp. 173-183, 2000.

[4] C. Alasalvar, F. Shahidi, C. M. Liyanapathirana, and T. Ohshima, "Turkish tombul hazelnut (Corylus avellana L.). 
1. Compositional characteristics," Journal of Agricultural and Food Chemistry, vol. 51, no. 13, pp. 3790-3796, 2003.

[5] W. H. Tian, L. S. Liang, and G. X. Wang, "Nutrient composition analysis of hazelnut kernel from different varieties," Food Science, vol. 33, pp. 265-269, 2012.

[6] X. H. Luo, Materia Medica for Dietotherapy, Chinese Medicine Publishing House, Beijing, China, 2007.

[7] L. Surhone, M. Tennoe, S. Henssonow, and C. Colchica, Corylus Heterophylla, Betascript Publishing, New York, NY, USA, 2010.

[8] X. F. Zhu, K. Yang, and Y. H. Zhao, "Comparison of active components content and antioxidant properties of Flat European hazelnut," Food Science, vol. 37, pp. 1-10, 2016.

[9] C. Alasalvar, F. Shahidi, T. Ohshima et al., "Turkish tombul hazelnut (Corylus avellanaL.). 2. Lipid characteristics and oxidative stability," Journal of Agricultural and Food Chemistry, vol. 51, no. 13, pp. 3797-3805, 2003.

[10] J. S. Bonvehí and F. V. Coll, "Oil content, stability and fatty acid composition of the main varieties of Catalonian Hazelnuts (Corylus avellana L.)," Food Chemistry, vol. 48, no. 3, pp. 237-241, 1993.

[11] E. Enrique, F. Pineda, T. Malek et al., "Sublingual immunotherapy for hazelnut food allergy: a randomized, doubleblind, placebo-controlled study with a standardized hazelnut extract," Journal of Allergy and Clinical Immunology, vol. 116, no. 5, pp. 1073-1079, 2005.

[12] Y. H. Li, F. R. Zheng, and C. X. Niu, "Study on processing technology and stability of hazelnut milk beverage," Beverage Industry, vol. 1, pp. 25-27, 2009.

[13] N. Bernat, M. Cháfer, A. Chiralt, and C. González-Martínez, "Hazelnut milk fermentation using probiotic Lactobacillus rhamnosus GG and inulin," International Journal of Food Science \& Technology, vol. 49, pp. 2553-2562, 2015.

[14] F. G. Kirbaslar and G. Erkmen, "Investigation of the effect of roasting temperature on the nutritive value of hazelnuts," Plant Foods for Human Nutrition, vol. 58, pp. 1-10, 2003.

[15] B. Matthäus and M. M. Özcan, "The comparison of properties of the oil and kernels of various hazelnuts from Germany and Turkey," European Journal of Lipid Science and Technology, vol. 114, no. 7, pp. 801-806, 2012.

[16] J. Parcerisa, J. Boatella, R. Codony, M. Rafecas, A. I. Castellote, and A. Romero, "Comparison of fatty acid and triacylglycerol compositions of different hazelnut varieties (Corylus avellana L.) cultivated in catalonia (Spain)," Journal of Agricultural and Food Chemistry, vol. 43, no. 1, pp. 13-16, 1995.

[17] C. Alasalvar, J. S. Amaral, and F. Shahidi, "Functional lipid characteristics of Turkish tombul hazelnut (Corylus avellana L.)," Journal of Agricultural and Food Chemistry, vol. 54, no. 26, pp. 10177-10183, 2006.

[18] COMTEX News Network, World Hazelnuts Market Report 2017-Analysis and Forecast to 2025, COMTEX News Network, New York, NY, USA, 2017.

[19] AOAC 925.40, Official Method of Analysis Moisture in Nuts and Nut Products First Action, Association of Official Analytical Chemists, Washington, DC, USA, 1925.

[20] D. Voet, Biochemistry, John Wily and Sons Inc., Hoboken, NJ, USA, 2nd edition, 1995.

[21] AOAC 2001.11, Official Method of Analysis Protein (Crude) in Animal Feed, Forage (Plant Tissue), Grain, and Oilseeds Block Digestion Method Using Copper Catalyst and Steam Distillation into Boric Acid First Action, Association of Official Analytical Chemists, Washington, DC, USA, 2001.

[22] GB 5009.9, Determination of Starch in Food, China Food and Drug Administration, Beijing, China, 2016.
[23] AOAC 2000.11, Official Method of Analysis Polydextrose in Foods Ion Chromotography First Action, Association of Official Analytical Chemists, Washington, DC, USA, 2000.

[24] AOAC 950.49, Official Method of Analysis Ash of Nuts and Nut Products Gravimetric Method First Action, Association of Official Analytical Chemists, Washington, DC, USA, 1950.

[25] AOAC 948.22, Official Method of Analysis Fat (Crude) in Nuts and Nut Products Gravimetric Methods First Action, Association of Official Analytical Chemists, Washington, DC, USA, 1948

[26] AOCS, Official Methods and Recommanded Pratics. 4. s.l. AOCS, American Oil Chemists Society, Urbana, IL, USA, 1990.

[27] A. İ. Köksal, N. Artik, A. Şimşek, and N. Güneş, "Nutrient composition of hazelnut (Corylus avellana L.) varieties cultivated in Turkey," Food Chemistry, vol. 99, no. 3, pp. 509-515, 2006.

[28] F. Shahidi, C. Alasalvar, and C. M. Liyana-Pathirana, "Antioxidant phytochemicals in hazelnut kernel (Corylus avellana L.) and hazelnut byproducts," Journal of Agricultural and Food Chemistry, vol. 55, no. 4, pp. 1212-1220, 2007.

[29] C. Bignami, G. Bertazza, V. Cristofori, and D. Troso, "Kernel quality and composition of hazelnut (Corylus avellana L.) cultivars," Acta Horticulturae, no. 686, pp. 477-484, 2005.

[30] B. W. Bolling, D. L. McKay, and J. B. Blumberg, "The phytochemical composition and antioxidant actions of tree nuts," Asia Pacific Journal of Clinical Nutrition, vol. 19, pp. 117-123, 2010.

[31] H. Zhao, C. Yu, and M. Li, "Effects of geographical origin, variety, season and their interactions on minerals in tea for traceability," Journal of Food Composition and Analysis, vol. 63, pp. 15-20, 2017.

[32] T. Caliskan and E. Cetiner, "Characterization studies on some hazelnut cultivars and types," Acta Horticulturae, vol. 445, pp. 1-11, 1997.

[33] R. Botta, C. Gianotti, and G. Me, "Kernel quality in hazelnut cultivars and selections analysed for sugars, lipids and fatty acid composition," Acta Horticulturae, vol. 445, no. 445, pp. 319-326, 1997.

[34] M. Thitisaksakul, R. C. Jiménez, M. C. Arias, and D. M. Beckles, "Effects of environmental factors on cereal starch biosynthesis and composition," Journal of Cereal Science, vol. 56, no. 1, pp. 67-80, 2012.

[35] J. Parcerisa, J. Boatella, R. Codony et al., "Influence of variety and geographical origin on the lipid fraction of hazelnuts (Corylus avellana L.) from Spain: I. Fatty acid compositionfluence of variety and geographical origin on the lipid fraction of hazelnuts (Corylus avellana L.) from Spain:I. Fatty acid composition," Food Chemistry, vol. 48, no. 4, pp. 411-414, 1993.

[36] Y. Xu and M. A. Hanna, "Composition and oxidative stabilities of oils extracted from hybrid hazelnuts grown in Nebraska, USA," International Journal of Food Science \& Technology, vol. 45, no. 11, pp. 2329-2336, 2010.

[37] K. S. Ebrahem, D. G. Richardson, R. M. Tetley, and S. A. Mehlenbacher, "Oil content, fatty acid composition, and vitamin E concentration of 17 hazelnut varieties, compared to other types of nuts and oil seeds," Acta Horticulturae, no. 351, pp. 685-692, 1994.

[38] M. Zec and M. Glibetic, "Health benefits of nut consumption," in Reference Module in Food Science, pp. 1-13, Elsevier, Amsterdam, Netherlands, 2018.

[39] H. Ciemniewska-Żytkiewicz, V. Verardo, F. Pasini, J. Bryś, and P. Koczon, "Determination of lipid and phenolic fraction 
in two hazelnut (Corylus avellana L.) cultivars grown in Poland," Food Chemistry, vol. 168, pp. 615-623, 2015.

[40] Z. Piravi-Vanak, J. B. Ghasemi, M. Ghavami, H. Ezzatpanah, and E. Zolfonoun, "The influence of growing region on fatty acids and sterol composition of Iranian olive oils by unsupervised clustering methods," Journal of the American Oil Chemists' Society, vol. 89, no. 3, pp. 371-378, 2012.

[41] J. C. Bada, M. León-Camacho, M. Prieto, P. Copovi, and L. Alonso, "Characterization of walnut oils (Juglans regia L.) from asturias, Spain," Journal of the American Oil Chemists' Society, vol. 87, no. 12, pp. 1469-1474, 2010.

[42] B. Paolo and B. Roberto, "Microsatellite variability and genetic structure in hazelnut (Corylus avellana L.) cultivars from different growing regions," Scientia Horticulturae, vol. 124, pp. 128-133, 2010.

[43] V. Cristofori, S. Ferramondo, G. Bertazza, and C. Bignami, "Nut and kernel traits and chemical composition of hazelnut (Corylus avellana L.) cultivars," Journal of the Science of Food and Agriculture, vol. 88, no. 6, pp. 1091-1098, 2008.

[44] C. Bignami, V. Cristofori, P. Ghini, E. Rugini, and L. Varvaro, "Effects of irrigation on growth and yield components of hazelnut (Corylus avellana L.) in central Italy," Acta Horticulturae, no. 845, pp. 309-314, 2009. 